\title{
ANALISIS PROFITABILITAS USAHA TERNAK BROILER PADA SKALA YANG BERBEDA DI KECAMATAN SUKOWONO KABUPATEN JEMBER
}

\author{
Analysis Profitability of Broiler Livestock Business at Different Scales in Sukowono District \\ Jember Regency
}

\author{
Achmad Riduwan, Anang Febri Prasetyo* \\ Department of Animal Husbandry, State Polytechnic of Jember \\ Lingkungan Panji, Tegalgede, Sumbersari, Jember, Jawa Timur 68124 \\ *E-mail: anangfebri@polije.ac.id \\ Submitted : August 26, $2019 \quad$ Accepted : March 27, 2020
}

\begin{abstract}
ABSTRAK
Tujuan penelitian ini untuk mengetahui tingkat profitabilitas usaha ternak broiler di Kecamatan Sukowono Kabupaten Jember. Penelitian ini merupakan penelitian deskriptif. Data diperoleh dengan wawancara terstruktur menggunakan kuisioner pada 28 peternak di Kecamatan Sukowono Kabupaten Jember. Sampel dibedakan menjadi dua skala berdasarkan populasi ternak yaitu skala 1 dengan populasi $<5.000$ ayam dan skala 2 dengan populasi $\geq 5.000$ ayam. Hasil penelitian menunjukkan pada skala 1 dan skala 2 mengalami kerugian pada dua periode awal, yaitu pada skala 1 sebesar $11,00 \%$ dan $-6,53 \%$, sedangkan pada skala 2 sebesar $-6,72 \%$ dan $-4,53 \%$. Peternak mendapatkan keuntungan pada periode ketiga yaitu, skala 1 sebesar 16,89\% dan skala 2 sebesar $12,53 \%$. Penelitian ini menunjukkan pasca pembatasan penggunaan antibiotik pada pakan menyebabkan peternak mengalami kerugian selama 2 periode.
\end{abstract}

Kata Kunci: Broiler, Pendapatan, Peternak, Profitabilitas, Skala.

\section{ABSTRACT}

The purpose of this study was to determine the level of profitability of broiler livestock businesses in Sukowono District, Jember Regency. This research was a descriptive study. Data were obtained by structured interviews using questionnaires in 28 farmers in Sukowono District. The samples were divided into two scales based on livestock population, first scale with population $<5.000$ broiler chicken and second scale population $\geq 5,000$ broiler. The results showed in first and second periods on both ownership scales. The results showed on a scale of $1^{\text {st }}$ and scale $2^{\text {nd }}$ suffered a loss in the initial two periods on first scale $11.00 \%$ and $-6.53 \%$, while on second scale $-6.72 \%,-4.53 \%$, farmers benefit in third period on first scale $16.89 \%$, second scale $12.53 \%$. This study showed that after limiting the use of antibiotics in feed, farmers have suffered losses for two periods.

Keywords: Broiler, Farmer, Income, Profitability, Scale.

\section{PENDAHULUAN}

Tujuan pembangunan pertanian sub sektor peternakan salah satunya adalah terpenuhinya kebutuhan pangan yang terus meningkat terutama daging. Perkembangan peternakan didominasi oleh usaha ternak ternak ayam komersial, terutama ayam pedaging (broiler). Usaha ternak broiler dianggap paling mampu untuk memenuhi kebutuhan daging bagi masyarakat karena fase produksinya yang relatif singkat.
Direktorat Jenderal Peternakan dan Kesehatan Hewan (2017) menyatakan bahwa populasi broiler pada tahun 2016 mencapai 1,6 miliar ekor meningkat sebesar $6,82 \%$ dan produksi daging sebesar 1,9 juta ton meningkat sebesar $17,02 \%$. Peningkatan populasi dan produksi broiler tersebut didorong oleh: 1) adanya perkembangan industri peternakan baik hulu maupun hilir, misalnya pabrik pakan, pembibitan, industri farmasi, rumah potong hewan, restoran dan lain-lain; 2) siklus produksi ayam pedaging 
yang relatif pendek dan perputaran modal relatif cepat; 3) mampu menyerap tenaga kerja; dan 4) potensi ekspor. Kabupaten Jember memiliki populasi yang cukup besar yaitu sebesar 5,83\% dari total populasi broiler di Jawa Timur atau sebesar 11.851 .934 ekor pada tahun 2017.

Usaha peternakan ayam selalu bertujuan untuk mendapatkan keuntungan. Keberlanjutan usaha peternakan broiler ditentukan oleh besarnya keuntungan yang diperoleh (Fatah, 1994). Biaya produksi ternak ayam pedaging sebagian besar (65-75\%) terserap pada biaya pakan (Mulyadi, 2014). Keuntungan usaha ternak broiler sangat ditentukan oleh nilai rasio konversi pakan/feed convertion ratio (FCR). Untuk mengoptimalkan fungsi pakan, banyak pabrik pakan menambahkan antibiotik ke dalam pakan yang diproduksinya (Priyanti, 2017). Barton (2000) melaporkan bahwa penggunaan antibiotik dapat meningkatkan produksi sekitar 3,9\% dan FCR sekitar 2,9\%.

Secara tegas Pemerintah Indonesia telah membatasi penggunaan antibiotik dalam pakan ternak sesuai dengan UU No.41 tahun 2014. Pembatasan ini dikhawatirkan dapat meningkatkan biaya produksi broiler dan mengurangi keuntungan peternak. Berdasarkan permasalahan tersebut, maka perlu dilakukan penelitian untuk membuktikan asumsi di atas. Penelitian ini bertujuan untuk mengetahui tingkat profitabilitas usaha peternakan broiler di Kecamatan Sukowono Kabupaten Jember.

\section{MATERI DAN METODE}

Penelitian ini dilakukan selama dua bulan (Desember 2018 - Januari 2019) di Kecamatan Sukowono Kabupaten Jember Provinsi Jawa Timur. Lokasi penelitian dipilih dengan pertimbangan daerah tersebut memiliki populasi ternak broiler paling banyak di Kabupaten Jember.

Penelitian ini merupakan penelitian deskriptif yang bertujuan mendeskripsikan suatu objek atau kegiatan (Darmawan 2013). Pengumpulan data dilakukan dengan wawancara menggunakan kuisioner terstruktur. Data yang diambil selama 3 periode produksi pemeliharaan broiler. Sampel berasal dari seluruh peternak broiler di Kecamatan Sukowono sebanyak 28 peternak. Sampel di kelompokkan menjadi 2 skala, yaitu skala 1 populasi $<5000$ ekor dan skala 2 populasi $\geq 5000$ ekor.

Parameter yang diamati yaitu struktur biaya produksi, pendapatan dan profitabilitas usaha peternakan broiler. Pendapatan usaha peternakan broiler diketahui menggunakan rumus menurut Sartono (2001) sebagai berikut :

$$
\begin{array}{ll}
\Pi & =\mathrm{TR}-\mathrm{TC} \\
\mathrm{TC} & =\mathrm{TFC}+\mathrm{TVC} \\
\mathrm{TR} & =\mathrm{Q} \times \mathrm{PQ}
\end{array}
$$

Keterangan :

TFC = Total biaya tetap

TVC = Total biaya tidak tetap

TR = Total Penerimaan (Rp/tahun)

$\mathrm{Q}=$ Jumlah Produksi Total (ekor/tahun)

PQ = Harga satuan produk (Rp/ekor)

$\Pi \quad=$ Pendapatan

$\mathrm{TR}=$ Total Penerimaan

TC $=$ Total biaya produksi

Analisis Profitabilitas dengan rumus sebagai berikut :

Profitabilitas $=\frac{\text { Penerimaan bersih }}{\text { Total biaya produksi }} \times 100 \%$

R/C Ratio, dengan rumus sebagai berikut :

$\mathrm{R} / \mathrm{C}$ Ratio $=\frac{\mathrm{TR}}{\mathrm{TC}}$

Keterangan :

$\mathrm{R} / \mathrm{C}$ Ratio = Efisiensi Biaya

TR $=$ Total Penerimaan

TC $\quad=$ Total Biaya

Pengambilan keputusan berdasarkan Payman (1993) :

- Apabila Nilai R/C Ratio < 1, usaha peternakan dinyatakan tidak layak untuk dikembangkan.

- Apabila Nilai R/C Ratio = 1, usaha peternakan dinyatakan tidak layak untuk dikembangkan.

- Apabila Nilai R/C Ratio > 1, usaha peternakan dinyatakan layak untuk dikembangkan.

\section{HASIL DAN PEMBAHASAN}

\section{Karakteristik Peternak}

Karakteristik secara umum dapat dilihat pada Tabel 1. Skala usaha ternak yang dimiliki oleh peternak dengan rata-rata 4.553,57 ekor. Menurut Gusasi dan Saade (2006) skala usaha menentukan tingkat pendapatan dan efisiensi usaha. Usia peternak rata-rata 37,93 tahun yang tergolong angkatan kerja produktif (Simanjuntak, 2002). Pendidikan peternak rata-rata 12,14 tahun, yaitu pendidikan formal SMA, semakin tinggi pendidikan maka semakin matang dalam mengelola usaha (Risqina et al., 2011). Pengalaman beternak rata-rata 4,96 tahun, semakin banyak pengalaman maka semakin banyak pelajaran yang diperoleh (Nitisemito dan Burhan, 2004). 
Tabel 1. Karakteristik Peternak

(Breeder Characteristics)

\begin{tabular}{ll}
\hline $\begin{array}{r}\text { Karakteristik Peternak } \\
\text { (Breeder Characteristics) }\end{array}$ & \multicolumn{1}{c}{$\begin{array}{c}\text { Rata-rata } \\
\text { (Average) }\end{array}$} \\
\hline Populasi (Ekor) & $4.553,57 \pm 2060,831$ \\
Umur (tahun) & $37,93 \pm 8,537$ \\
Pendidikan (tahun) & $12,14 \pm 2,240$ \\
Pengalaman (tahun) & $4,96 \pm 3,012$ \\
\hline
\end{tabular}

\section{Biaya Produksi}

Biaya produksi adalah hasil penjumlahan biaya tetap dan biaya tidak tetap atau variabel (Rahardja dan Mandala, 2012). Menurut Utomo et al. (2015) yang termasuk komponen biaya variabel yang dikeluarkan oleh peternak plasma, meliputi: biaya pembelian DOC, upah tenaga kerja, biaya gas pemanas, biaya listrik, Pajak Bumi dan Bangunan (PBB), dan biaya retribusi. Biaya produksi adalah jumlah keseluruhan dari biaya tetap dan biaya variabel. Jumlah dan persentase dari berbagai komponen biaya produksi disajikan pada Tabel 2 dan Tabel 3

Hasil penelitian menunjukkan rata-rata biaya tetap yang dikeluarkan oleh peternak skala 2 lebih besar dibandingkan dengan peternak skala 1. Menurut Sutojo (2000) biaya tetap adalah biaya yang jumlah totalnya tetap dan tidak dipengaruhi oleh perubahan volume produksi. Hasil penelitian menunjukkan bahwa biaya pakan yang dikeluarkan peternak skala 1 dan 2 setelah pelarangan Antibiotic Growth Promotor (AGP) pada pakan diberhentikan, yaitu sebesar $74,5 \%$ dan 72,7\%. Sesuai dengan pendapat Azizah et al. (2013) bahwa biaya pakan merupakan biaya yang paling besar pada usaha peternakan broiler yang berkisar antara 60 - 80\% dari total biaya.

Berdasarkan Tabel 2 dan Tabel 3 diketahui biaya total terbesar pada usaha peternakan broiler di Kecamatan Sukowono Kabupaten Jember dikeluarkan oleh peternak skala 2 ( $\geq 5000$ ekor), sedangkan biaya total terkecil oleh peternak skala 1 (<5000 ekor), maka dapat dinyatakan bahwa semakin tinggi skala usaha yang dikelola peternak maka semakin tinggi total biaya yang dikeluarkan peternak broiler untuk melaksanakan pemeliharaan. Hal ini sejalan dengan penelitian Paly (2016), yaitu total biaya produksi skala 1 (3.000 - 5.000 ekor) paling sedikit Rp. 115.490.000, dibandingkan dengan biaya pada skala 2 (5.001 - 7.000 ekor) Rp. 143.375.000 dan Skala $3 \quad$ (7.001 - 10.000 ekor) dengan biaya tertinggi Rp. 180.000.000, sehingga dapat dinyatakan bahwa semakin besar skala usaha, semakin tinggi biaya produksi yang dikeluarkan.

Tabel 2. Biaya produksi usaha ternak broiler pada skala 1

(Production costs for broiler livestock business on $1^{\text {st }}$ scale)

\begin{tabular}{|c|c|c|c|c|c|c|}
\hline \multirow{3}{*}{$\begin{array}{c}\text { Biaya Produksi } \\
\text { (Production Costs) }\end{array}$} & \multicolumn{6}{|c|}{$\begin{array}{c}\text { Skala 1 } \\
\left(1^{\text {st }} \text { Scale }\right)\end{array}$} \\
\hline & \multicolumn{2}{|c|}{$\begin{array}{c}\text { Periode 1 } \\
\left(1^{\text {st }} \text { Period }\right)\end{array}$} & \multicolumn{2}{|c|}{$\begin{array}{c}\text { Periode } 2 \\
\left(2^{\text {nd }} \text { Period }\right) \\
\end{array}$} & \multicolumn{2}{|c|}{$\begin{array}{c}\text { Periode } 3 \\
\left(3^{\text {rd }} \text { Period }\right)\end{array}$} \\
\hline & $\mathbf{R p}$ & $\%$ & $\mathbf{R p}$ & $\%$ & Rp & $\%$ \\
\hline Biaya Tetap (Fix Cost) & $\mathbf{1 . 8 2 6 . 7 2 7}$ & 1,90 & 1.826.727 & 1,94 & 1.826 .727 & 1,98 \\
\hline $\begin{array}{l}\text { Biaya tidak tetap (Variabel } \\
\text { Cost) }\end{array}$ & & & & & & \\
\hline $\begin{array}{l}\text { Biaya Pakan } \\
(\text { Feed Cost })\end{array}$ & 69.722 .111 & 72,52 & 68.089 .861 & 72,38 & 65.571 .250 & 71,00 \\
\hline $\begin{array}{l}\text { Biaya DOC } \\
\text { (Day Old Chick Cost) }\end{array}$ & 18.979 .861 & 19,74 & 18.967.361 & 20,16 & 19.960 .417 & 21,61 \\
\hline $\begin{array}{l}\text { Biaya Kesehatan } \\
\text { (Health Cost) }\end{array}$ & 2.573 .071 & 2,68 & 2.155 .697 & 2,29 & 1.963 .778 & 2,13 \\
\hline $\begin{array}{l}\text { Biaya Tenaga Kerja } \\
\text { (Labor Cost) }\end{array}$ & 1.797 .777 & 1,87 & 1.797 .777 & 1,91 & 1.797 .777 & 1,95 \\
\hline $\begin{array}{l}\text { Biaya Manajemen } \\
\text { (Managemet Cost) }\end{array}$ & 1.238 .667 & 1,28 & 1.238 .667 & 1,31 & 1.238 .667 & 1,34 \\
\hline $\begin{array}{l}\text { Jumlah Biaya Produksi } \\
\text { (Total Production Cost) }\end{array}$ & 96.138.214 & 100,00 & 94.076.090 & 100,00 & 92.358.615 & 100,00 \\
\hline
\end{tabular}

Sumber: Data diolah (2019) 
Tabel 3. Biaya produksi usaha ternak broiler pada skala 2

\begin{tabular}{|c|c|c|c|c|c|c|}
\hline \multirow[t]{3}{*}{$\begin{array}{c}\text { Biaya Produksi } \\
\text { (Production Costs) }\end{array}$} & \multicolumn{6}{|c|}{$\begin{array}{c}\text { Skala } 2 \\
\left(2^{\text {nd }} \text { Scale }\right)\end{array}$} \\
\hline & \multicolumn{2}{|c|}{$\begin{array}{l}\text { Periode 1 } \\
\left(1^{\text {st }} \text { Period }\right)\end{array}$} & \multicolumn{2}{|c|}{$\begin{array}{c}\text { Periode } 2 \\
\left(2^{\text {nd }} \text { Period }\right) \\
\end{array}$} & \multicolumn{2}{|c|}{$\begin{array}{c}\text { Periode } 3 \\
\left(3^{r d} \text { Period }\right)\end{array}$} \\
\hline & Rp & $\%$ & Rp & $\%$ & Rp & $\%$ \\
\hline $\begin{array}{l}\text { Biaya Tetap (Fix Cost) } \\
\text { Biaya tidak tetap } \\
\text { (Variabel Cost) }\end{array}$ & 3.108.850 & 1,42 & 3.108 .850 & 1,42 & 3.108 .850 & 1,42 \\
\hline $\begin{array}{l}\text { Biaya Pakan } \\
\text { (Feed Cost) }\end{array}$ & 160.311 .625 & 73,00 & 159.368 .125 & 72,92 & 157.662 .500 & 72,40 \\
\hline $\begin{array}{l}\text { Biaya DOC } \\
\text { (Day Old Chick Cost) }\end{array}$ & 42.483 .500 & 19,35 & 42.772 .250 & 19,57 & 43.976 .000 & 20,19 \\
\hline $\begin{array}{l}\text { Biaya Kesehatan } \\
\text { (Health Cost) }\end{array}$ & 5.935 .500 & 2,70 & 5.532 .000 & 2,53 & 5.259 .000 & 2,41 \\
\hline $\begin{array}{l}\text { Biaya Tenaga Kerja } \\
\text { (Labor Cost) }\end{array}$ & 4.272 .000 & 1,95 & 4.272 .000 & 1,96 & 4.272 .000 & 1,96 \\
\hline $\begin{array}{l}\text { Biaya Manajemen } \\
\text { (Managemet Cost) }\end{array}$ & 3.488 .600 & 1,58 & 3.488 .600 & 1,6 & 3.488 .600 & 1,6 \\
\hline $\begin{array}{l}\text { Jumlah Biaya Produksi } \\
\text { (Total Production Cost) }\end{array}$ & 219.600.075 & 100,00 & 218.541.825 & $\begin{array}{r}100,0 \\
0\end{array}$ & 217.766 .950 & 100,00 \\
\hline
\end{tabular}

Sumber: Data diolah (2019)

Tabel 4. Penerimaan usaha ternak broiler skala 1

(Broiler livestock business revenue on $1^{\text {st }}$ scale)

\begin{tabular}{|c|c|c|c|c|c|c|}
\hline \multirow{3}{*}{$\begin{array}{c}\text { Penerimaan } \\
\text { (Reveneu) }\end{array}$} & \multicolumn{6}{|c|}{$\begin{array}{c}\text { Skala 1 } \\
\left(1^{\text {st }} \text { Scale }\right)\end{array}$} \\
\hline & \multicolumn{2}{|c|}{$\begin{array}{c}\text { Periode } 1 \\
\left(1^{\text {st }} \text { Period }\right)\end{array}$} & \multicolumn{2}{|c|}{$\begin{array}{c}\text { Periode } 2 \\
\left(2^{\text {nd }} \text { Period }\right)\end{array}$} & \multicolumn{2}{|c|}{$\begin{array}{c}\text { Periode } 3 \\
\left(3^{r d} \text { Period }\right)\end{array}$} \\
\hline & Rp & $\%$ & $\mathbf{R p}$ & $\%$ & $\mathbf{R p}$ & $\%$ \\
\hline Penjualan Ayam & 85.422 .287 & 99,71 & 87.784 .405 & 99,72 & 106.582 .027 & 99,77 \\
\hline Penjualan Ekskreta & 102.778 & 0,12 & 102.778 & 0,12 & 102.778 & 0,10 \\
\hline Penjualan Karung & 145.556 & 0,17 & 145.556 & 0,17 & 145.556 & 0,14 \\
\hline $\begin{array}{l}\text { Total Penerimaan } \\
\text { (Total Revenue) }\end{array}$ & 85.670 .621 & 100,00 & 88.032.739 & 100,00 & 106.830 .360 & 100,00 \\
\hline
\end{tabular}

Sumber: Data diolah (2019)

\section{Penerimaan}

Penerimaan suatu usaha merupakan perkalian antara faktor produksi dengan harga jual. Penerimaan plasma berasal dari hasil penjualan broiler, penjualan ekskreta dan penjualan karung bekas pakan. Struktur penerimaan plasma pada berbagai skala kepemilikan disajikan pada Tabel 4 dan Tabel 5 yang menunjukkan total penerimaan yang diperoleh peternakan broiler di Kecamatan Sukowono Kabupaten Jember pada skala 2 ( $\geq 5.000$ ekor) memperoleh penerimaan tertinggi yaitu sebesar Rp. 230.160.470 dan jumlah penerimaan paling rendah diperoleh peternak dengan skala 1 (<5.000 ekor), yaitu sebesar Rp 98.629.084. Hasil penelitian ini menunjukkan bahwa banyaknya populasi broiler yang dipelihara mempengaruhi hasil penerimaan yang diperoleh peternak. Hal ini seperti pernyataan dari Paly (2016), yaitu peternak plasma pada skala 3 (5.001 - 7.000 ekor) Rp. 199.650.000 dan skala 2 (7.001 - 10.000 ekor) Rp. 160.500 .000 memperoleh penerimaan tertinggi, dibandingkan pada skala 3 (3.000 - 5.000 ekor) Rp. 126.245 .000 yang memiliki penerimaan terendah, sehingga hal ini menunjukkan bahwa skala kepemilikan usaha peternakan broiler mempengaruhi penerimaan. 
Tabel 5. Penerimaan usaha ternak broiler skala 2 (Broiler livestock business revenue on $2^{\text {nd }}$ scale)

\begin{tabular}{|c|c|c|c|c|c|c|}
\hline \multirow{3}{*}{$\begin{array}{c}\text { Penerimaan } \\
\text { (Reveneu) }\end{array}$} & \multicolumn{6}{|c|}{$\begin{array}{c}\text { Skala } 2 \\
\left(2^{n d} \text { Scale }\right)\end{array}$} \\
\hline & \multicolumn{2}{|c|}{$\begin{array}{c}\text { Periode 1 } \\
\left(1^{\text {st }} \text { Period }\right)\end{array}$} & \multicolumn{2}{|c|}{$\begin{array}{c}\text { Periode } 2 \\
\left(2^{\text {nd }} \text { Period }\right)\end{array}$} & \multicolumn{2}{|c|}{$\begin{array}{c}\text { Periode } 3 \\
\left(3^{r d} \text { Period }\right)\end{array}$} \\
\hline & Rp & $\%$ & Rp & $\%$ & Rp & $\%$ \\
\hline Penjualan Ayam & 205.173 .529 & 99,69 & 208.514 .709 & 99,69 & 243.862 .586 & 99,74 \\
\hline Penjualan Ekskreta & 230.000 & 0,11 & 230.000 & 0,11 & 230.000 & 0,09 \\
\hline Penjualan Karung & 415.000 & 0,20 & 415.000 & 0,20 & 415.000 & 0,17 \\
\hline $\begin{array}{l}\text { Total Penerimaan } \\
\text { (Total Revenue) }\end{array}$ & 205.818.529 & 100,00 & 209.159.709 & 100,00 & 244.507.586 & 100,00 \\
\hline
\end{tabular}

Sumber: Data diolah (2019)

Tabel 6. Pendapatan usaha peternakan broiler (Broiler livestock business income)

\begin{tabular}{|c|c|c|c|c|c|c|}
\hline \multirow{2}{*}{$\begin{array}{l}\text { Periode } \\
\text { (Period) }\end{array}$} & \multicolumn{3}{|c|}{$\begin{array}{c}\text { Skala } 1<5.000 \text { ekor } \\
(\text { Scale } 1<5.000 \text { chicken })\end{array}$} & \multicolumn{3}{|c|}{$\begin{array}{c}\text { Skala } 2 \geq 5.000 \text { ekor } \\
(\text { Scale } 2 \geq 5.000 \text { chicken })\end{array}$} \\
\hline & $\begin{array}{c}\text { Pendapatan } \\
\text { (Income) } \\
(\mathbf{R p})\end{array}$ & $\begin{array}{c}\text { Keuntungan } \\
\text { (Profitabilitas) } \\
(\%)\end{array}$ & $\begin{array}{l}\mathbf{R} / \mathbf{C} \\
\text { Ratio }\end{array}$ & $\begin{array}{c}\text { Pendapatan } \\
\text { (Income) } \\
(\mathbf{R p})\end{array}$ & $\begin{array}{c}\text { Keuntungan } \\
\text { (Profitabilitas) } \\
(\%)\end{array}$ & $\begin{array}{l}\mathrm{R} / \mathrm{C} \\
\text { Ratio }\end{array}$ \\
\hline 1 & $(10.467 .594)$ & $-11,00$ & 0,89 & $(13.781 .546)$ & $-6,72$ & 0,94 \\
\hline 2 & $(6.043 .352)$ & $-6,53$ & 0,94 & $(9.382 .116)$ & $-4,53$ & 0,96 \\
\hline 3 & 14.471 .745 & 16,89 & 1,16 & 26.740 .636 & 12,53 & 1,12 \\
\hline
\end{tabular}

Sumber: Data diolah (2019)

\section{Pendapatan}

Pendapatan adalah keuntungan bersih yang diperoleh dari selisih antara total penerimaan dengan biaya produksi. Berdasarkan Tabel 6 dapat dikatakan bahwa pada periode pertama dan kedua peternak mengalami kerugian, baik pada skala 1 maupun skala 2. Pada periode ketiga, pada skala 1 mendapatkan keuntungan sebesar Rp. 14.471.745; sedangkan skala 2 mendapatkan keuntungan sebesar Rp. 26.740.636. Pendapatan pada skala 2 lebih besar dibandingkan pada skala 1, sehingga dapat disimpulkan semakin besar populasi suatu usaha maka semakin tinggi pula pendapatannya. Hal ini sesuai dengan hasil penelitian Utomo et al. (2015) bahwa skala usaha yang semakin besar atau semakin banyak populasi broiler yang dibudidayakan semakin tinggi pula pendapatan yang diperoleh peternak.

\section{Profitabilitas}

Profitabilitas diperoleh dengan cara membandingkan antara pendapatan dengan biaya produksi yang dinyatakan dalam bentuk persentase. Pada skala 1 secara berturut-turut memiliki profitabilitas sebesar $-11 \% ;-6,5 \%$; dan $16,89 \%$. Sedangkan pada skala 2 secara berturut turut memiliki profitabilitas sebesar -6,72\%; $6,53 \%$; dan $12,53 \%$. Berdasarkan angka tersebut terdapat kerugian di awal penerapan pembatasan antibiotik dalam pakan. Permasalahan diawal periode pasca pelarangan AGP pada pakan, banyak peternak mengeluh dengan kondisi ayam yang lesu, nafsu makan tidak ada, bobot badan rendah, mortalitas tinggi/angka kematian pada ayam tinggi dan pemanenan menjadi terlambat. Kon dan Rai (2016) menyatakan bahwa pemberhentian antibiotik dalam pakan mempengaruhi pertumbuhan bobot badan ternak yang kurang maksimal sehingga dapat menimbulkan kerugian pada peternak.

\section{R/C Ratio}

Return of cost ( $\mathrm{R} / \mathrm{C}$ ratio) dihitung dengan cara membagi total hasil produksi dengan total biaya produksi per ekor satu periode pemeliharaan. Berdasarkan Tabel 6 dapat dilihat bahwa terdapat angka R/C. Rasio dari usaha peternakan broiler skala 1 dan skala 2 tidak terlihat perbedaan. Hasil penelitian menunjukkan bahwa R/C tiap periode sangat berbeda, yaitu pada periode 1 dan $2, \mathrm{R} / \mathrm{C}<1$ yang berarti usaha pada periode tersebut tidak menguntungkan, sedangkan pada periode $3 \mathrm{R} / \mathrm{C}>1$ yang berarti usaha pada periode tersebut menguntungkan. Hal ini dapat disimpulkan bahwa kebijakan pemerintah mengenai pembatasan antibiotik pada pakan ternak dapat mempengaruhi profitabilitas usaha ternak ayam broiler. 


\section{SIMPULAN}

Profitabilitas pada usaha peternakan broiler di Kecamatan Sukowono Kabupaten Jember pasca pembatasan penggunaan antibiotik pada pakan mengalami kerugian pada periode satu dan dua di kedua skala yang berbeda. Keuntungan diperoleh kembali pada periode ketiga masa pemeliharaan.

\section{DAFTAR PUSTAKA}

Azizah, N., D.H. Utami, dan B.A. Nugroho. 2013. Analisis Pola Kemitraan Usaha Peternakan Ayam Pedaging sistem closed house di Plandaan Kabupaten Jombang. J. Ilmu Ilmu Peternakan 23(2): 1 - 5.

Badan Pusat Statistik. 2018. Statistik Penduduk Indonesia dan Populasi Ayam Ras Pedaging Jawa Timur 2018. Badan Pusat Statistik. Sidikalang.

Barton, M.D. 2000. Antibiotic Use in Animal Feed and its Impact on Human Health. Nutr. Res. 13: 279 - 299.

Darmawan, D. 2013. Metode Penelitian Kuantitatif. Remaja Rosdakarya. Bandung.

Dinas Peternakan Provinsi Jawa Timur. 2017. East Java Livestock Services. Data Populasi Ternak Unggas di Kabupaten Jember. Jember.

Fatah. 1994. Evaluasi Proyek. Aspek Finansial Pada Proyek Mikro. CV. Asona. Jakarta.

Gusasi, A. dan M.A. Saade. 2006. Analisis Pendapatan dan Efisiensi Usaha Ternak Ayam Potong pada Usaha Skala Kecil. $J$. Agri sistem. 2(1): 1 - 7 .

Kon, K and M. Rai. 2016. Antibiotic Resistance (Mechanisms and New Antimicronbial Approaches). Elsevier. London.

Mulyadi. 2014. Buku Lengkap Beternak dan Berbisnis Ayam Kampung, Ayam Pedaging, dan Ayam Arab. Flash Books. Yogyakarta.

Nitisemito, A.S dan M.U. Burhan. 2004. Wawasan Studi Kelayakan dan Evaluasi Proyek. Bumi Aksa. Jakarta.

Paly, M.B. 2016. Analisis Profitabilitas Peternakan Broiler Pola Kemitraan Berdasarkan Skala Kepemilikan di Kecamatan Bontonompo Kabupaten Gowa. J. Ilmu dan Industri Peternakan 3(1): 64-78.

Payman, S. 1993. Pengantar Evaluasi Proyek. Gramedia. Jakarta.

Priyanti, A. 2017. Kebijakan Pengendalian Penggunaan Antibiotic Growth Promoters dan Ractopamine dalam mendukung Keamanan Pangan Nasional. Pusat Penelitian dan Pengembangan Peternakan. Bogor.

Rahardja, P. dan M. Mandala. 2010. Teori Ekonomi Mikro. Fakultas Ekonomi Universitas Indonesia. Jakarta.

Risqina, L. Jannah, E.I. Rianto dan S. Santoso. 2011. Analisis Pendapatan peternak sapi potong dan Sapi Bakalan Karapan di Pulau Sapudi di Kabupaten Sumenep. J. Ilmu dan Teknologi Peternakan 1(3): 8 - 12.

Sartono, A. 2001. Manajemen Keuangan: Teori dan Aplikasi. Edisi 4. BPFE. Yogyakarta.

Simanjuntak, P. 2002. Pengantar Sumber Daya Manusia. Lembaga Penerbit UI. Jakarta.

Sutojo, S. 2000. Mengenal Arti Penggunaan Neraca Perusahaan. PT. Damar Mulia Perkasa. Jakarta.

Utomo, H.R., H. Setiyawan dan S.I. Santoso. 2015. Analisis Profitabilitas Usaha Peternakan Ayam Broiler dengan Pola Kemitraan di Kecamatan Limbangan Kabupaten Kendal. Anim. Agric. J. 4(1): 7-14. 